Editor's Note: In 2003, the Society for Neuroscience initiated the Science Educator Award to recognize an outstanding neuroscientist who has made significant contributions to the education of the public (http://www.sfn.org/content/Programs/AwardsandPrizes/sea.html). The first recipient was Eric Chudler, $\mathrm{PhD}$, at the University of Washington. For more on his activities, see http://faculty.washington.edu/chudler/ehceduc.html. The winner for 2004 was Rochelle Schwartz-Bloom, PhD, at Duke University Medical Center. In collaboration with the Committee on Neuroscience Literacy, the Journal asked Dr. Schwartz-Bloom to give us some of her views on neuroscience education with the hope of spurring all of us into action.

\title{
Science Education: A Neuroscientist's View of Translational Medicine
}

\author{
Rochelle Schwartz-Bloom \\ Department of Pharmacology and Cancer Biology and Department of Neurobiology, Duke University Medical Center, Durham, North Carolina 27710
}

The big buzzword these days is "translational medicine." We've all heard it, it's what the National Institutes of Health (NIH) is funding, it's what Congress wants, it's what the public wants. Basic scientists must demonstrate and articulate how their research findings can lead to the improvement of human health. As neuroscientists, we are fortunate because we study an area that is inherently interesting to most folks. When I meet someone who asks what I do, I tell them about my neuroscience research. Often, the response is something like, "the brain-wow, that's cool." And then they start asking questions. Many of you have probably experienced the same reaction. Over the years, it has been clear to me that the general population knows relatively little about what scientists really do, and given the sorry state of affairs with our science education at the K-12 level, we are facing an increasing danger of becoming a society that is science illiterate. Studies show that high school students in the United States still rate poorly in science and math achievement compared with their international peers (National Center for Educational Statistics, 1998). Moreover, results from the 2003 ACT college entrance exam re-

Received April 28, 2005; revised May 3, 2005; accepted May 3, 2005.

Correspondence should be addressed to Dr. Rochelle D. Schwartz-Bloom, Department of Pharmacology and Cancer Biology, Box 3813, Duke University Medical Center, Durham, NC 27710. E-mail: schwa001@duke.edu.

DOI:10.1523/JNEUROSCI.1693-05.2005

Copyright $\odot 2005$ Society for Neuroscience

0270-6474/05/255667-03\$15.00/0 veal that only $26 \%$ of high school students taking the test are prepared for college biology (ACT, 2003).

As basic scientists, many of us have engaged in translational medicine long before the term became fashionable. We've pursued an area of research that will someday lead to the development of new therapies, whether pharmacological, behavioral, or genetic, to treat disease. But I've always felt that we scientists have an obligation to help the rest of society understand what we do and what it means. What good is it if we make wonderful discoveries and publish our findings in scientific journals but the public doesn't understand what we discover? Shouldn't our society have the basic tools to understand science so they can make informed decisions about their lives? A lack of science literacy at the K-12 level creates future adults who are science illiterate. And when these folks go to the polls, they may make ill-informed decisions as they cast their ballots. I don't need to mention all of the science-related topics that have become political issues [and many policies get made based on misinformation (presumably unintentional)]. So, to me, translational medicine also means articulating what we do as scientists to the public and legislators, to help them better understand our science and how it affects their lives and their health. I've done my best to talk to students about neuroscience and my own research and what it means. I've hosted high school students in my labora- tory, given talks to students participating in summer research programs at my university, and traveled to high schools to give talks as well. It's likely that many of you have participated in similar activities.

But, I realized that I needed to do more. Based on my reading and on talking with high school teachers, I felt that something was missing in science education, at least at the high school level. Children have great interest in science, but it seems that as they become high school students, the interest dies off. Although there are many reasons for this, perhaps we scientists could help restore that interest by bringing our field into the classroom. In fact, research in developmental and cognitive psychology supports the idea that information embedded within meaningful contexts and applications fosters learning (Brooks and Brooks, 1993). Furthermore, teaching practices and topics that arouse student interest can help motivate students to learn and increase achievement (Sandoval, 1995). Although there is a paucity of research on the specific topics of interest to students, topics considered to be inherently interesting (especially to students) include death, danger, disease, injury, sex, and romance (Shank, 1979).

In this regard, I surmised that high school students may also be very interested in the brain, and how drugs affect their bodies (I speak as a pharmacologist here too). So, $\sim 12$ years ago, I decided to spend some of my sabbatical time "test- 


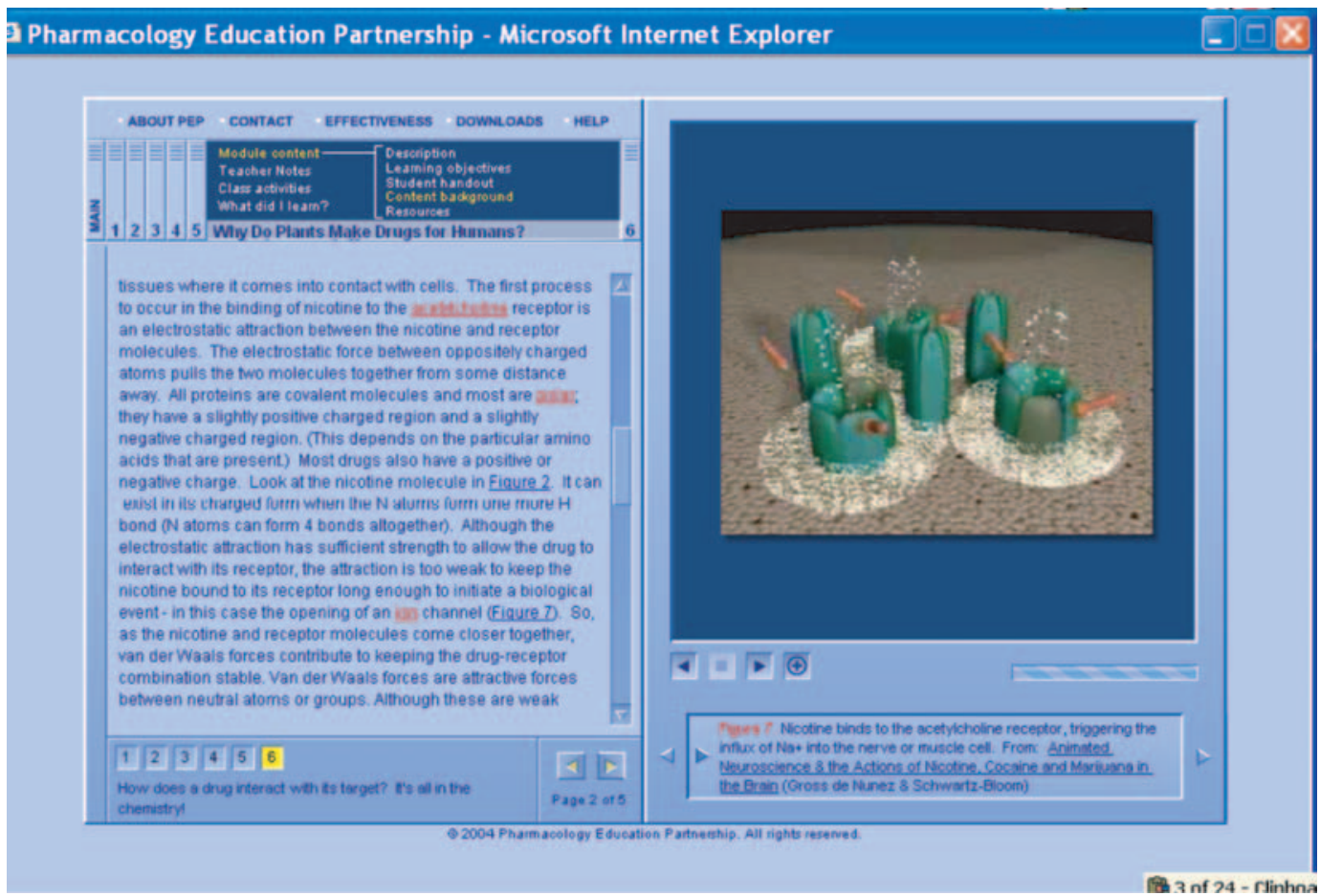

Figure 1. A page from the PEP website (www.thepepproject.net), module 5 ("Why Do Plants Make Drugs for Humans?"), shows the science content on the left and an animation of acetylcholine binding to acetylcholine receptors to open ion channels on the right. The animation continues to show how nicotine competes with acetylcholine. The animated clip is taken from the film "Animated Neuroscience. .. " (Gross de Núñez and Schwartz-Bloom, 1997)

ing" my theory. I visited a chemistry class at the nearby North Carolina School for Science and Math, and when the teacher (Myra Halpin) taught about oxidation and reduction, I followed up with a lecture on oxidation, but using a context to explain how methamphetamine kills neurons. The kids didn't stop asking questions, and they didn't get up when the bell rang. Thus, we decided to apply for a science education grant (R25) from the National Institute on Drug Abuse (NIDA) to develop a curriculum for high school biology and chemistry students. The overall objective of our partnership [the Pharmacology Education Partnership (PEP)] was to help high school students learn biology and chemistry better by presenting basic concepts within the context of pharmacology topics that are relevant to their lives, with a focus on drug abuse and the brain. We developed instructional materials, provided teacher training in basic principles of pharmacology, neuroscience, and drug abuse, field-tested the materials, and performed a rigorous analysis of the data (Schwartz-Bloom and Halpin, 2003).

The PEP curriculum includes a series of modules that integrate biology and chemistry. The topics, which have catchy titles such as "Acids, Bases, and Cocaine
Addicts," "How Drugs Kill Neurons; It's Radical!" and "Military Pharmacology: It Takes Nerves," present many basic biology and chemistry principles that are part of the standard high school curriculum. We tested students for knowledge of these principles after using the modules in their classes compared with students who used their standard curriculum $(n=3875)$. The more PEP modules used, the better they scored (Schwartz-Bloom and Halpin, 2003). A highlight of the program is the interactive website (www.thepepproject.net), which can be used by both teachers and students. A page from the module "Why Do Plants Make Drugs for $\mathrm{Hu}-$ mans" is shown in Figure 1.

An important part of the PEP program was the professional development. We provided workshops for teachers to learn basic principles of pharmacology, neuroscience, and drug abuse, using a 1 week, full-day, or distance-learning format. In each case, knowledge gain was long-term; teachers' scores on posttests at the conclusion of the workshops were maintained for at least 1 year (Schwartz-Bloom and Halpin, 2005). In fact, attendance at the workshop was a significant predictor of knowledge gain in their students (Schwartz-Bloom and Halpin, 2003). We continue to provide shorter versions of these workshops at the National Science Teachers Association meeting with funding from NIDA's science education program (www.nida.nih.gov).

Currently, there is a national call to enhance professional development for teachers; although teachers have considerable training in "how" to teach science, the training in science content lags far behind. As stated by Sandra Feldman, president of the American Federation of Teachers, "they can't teach what they don't know." Second, there is strong national interest in building partnerships to strengthen science curricula and instruction at the K-12 level by involving experts from the sciences in higher-education institutions (that's us!). Both of these initiatives have received increased federal funding, despite the decline in $\mathrm{NIH}$ and National Science Foundation (NSF) research support. Here is where we neuroscientists can make a major contribution to science education as well as translational medicine. The Society for Neuroscience has helped lay the groundwork for neuroscientists to become involved; it created the Committee on Neuroscience Literacy in 1989, which brings high school teachers and students to the Society for Neuroscience annual meeting and also 
develops Short Courses on topics related to bringing neuroscience literacy to the K-12 population. More recently, the Society for Neuroscience took another major step and created the Science Educator Award, to highlight the accomplishments of neuroscientists who have devoted their time to help the public understand neuroscience. As a recipient of the 2004 Science Educator Award, I urge all neuroscientists to do whatever you can to help translate science to the K-12 community and the public.* They need you.

Teaching resources for neuroscientists that I have produced can be found at the following sites:

The Pharmacology Education Partnership, www.theppepproject.net.

"Animated Neuroscience and the Action of Nicotine, Cocaine, and Marijuana in the Brain" (three-dimensional computeranimated video), www.films.com (available in VHS and DVD formats).

*For ideas on how you can get involved, browse the "Teaching of Neuroscience" posters at the Annual Meeting of the Society for Neuroscience or attend one of the Short Courses in Neuroscience literacy.
"The Brain and the Actions of Cocaine, Opiates, and Marijuana," http://www. drugabuse.gov/pubs/teaching/Teaching. html.

"The Neurobiology of Drug Addiction," http://www.drugabuse.gov/pubs/ teaching/Teaching2/Teaching.html.

"The Neurobiology of Ecstasy (MDMA)," http://www.drugabuse.gov/ pubs/teaching/Teaching4/Teaching.html.

Science education links, including funding sources:

NIH Office of Science Education, http:// science.education.nih.gov/home2.nsf/index. htm.

NIDA Science Education Resources, http://www.nida.nih.gov/parent-teacher. html.

NSF Education and Human Resources, http://www.nsf.gov/dir/index.jsp?org=EHR.

NSF Elementary, Secondary, and Informal Education, http://www.nsf.gov/ div/index.jsp?org $=$ ESIE.

\section{References}

ACT 2003 test results. http://www.act.org/news/ releases/2003/8-20-03.html.

Brooks JG, Brooks MG (1993) In search of understanding: the case of constructivist classrooms. Alexandria, VA: Association for Supervision and Curriculum Development.

Gross de Núñez G, Schwartz-Bloom RD (1997) Animated neuroscience and the action of nicotine, cocaine, and marijuana in the brain. Available at www.films.com.

National Center for Educational Statistics (1998) Pursuing excellence: a study of US twelfthgrade mathematics and science teaching, learning, curriculum, and achievement in international context. Third International Mathematics and Science Survey. Washington, DC: United States Government Printing Office.

Sandoval J (1995) Teaching in subject matter areas: science. Annu Rev Psychol 46: 355-374.

Schwartz-Bloom RD, Halpin MJ (2003) Integration of pharmacology topics in high school biology and chemistry classes improves performance. J Res Sci Teach 40:922-938.

Schwartz-Bloom RD, Halpin MJ (2005) Professional development for high school teachers in pharmacology improves student performance in their biology and chemistry classes. Soc Neurosci Abstr, in press.

Shank RC (1979) Interestingness: controlling inferences. Artif Intel 12:273-297. 